\title{
Informação versus desinformação: a crise sanitária da Covid-19 e o papel da autoridade médica na divulgação de conhecimentos científicos
}

\author{
Marcio da Silva GRANEZ ${ }^{1}$ \\ Cristiane Portela de CARVALHO ${ }^{2}$
}

Resumo:

O presente artigo analisa o fenômeno da desinformação no discurso da autoridade médica, no contexto da crise sanitária da Covid-19. O referencial teórico-metodológico inclui autores como Epstein (2002), Mayor e Forti (1998), para as questões relacionadas à mídia, à ciência e ao poder; e teóricos da análise do discurso, a exemplo de Maingueneau (2004). A coleta dos dados se deteve em matérias verificadas pelo site de checagem do Núcleo de Pesquisa em Comunicação e Jornalismo - NUJOC, da Universidade Federal do Piauí. O corpus da pesquisa é composto por dez matérias em que um profissional da área médica enuncia recomendações sobre a pandemia. A análise consistiu na identificação dos enunciadores e suas posições discursivas frente ao conhecimento científico. Concluiu-se que o saber individual dos médicos mostra-se em conflito com o saber institucionalizado da área da saúde, e que as redes sociais desempenham um papel relevante nesse conflito, fornecendo os meios para a divulgação de desinformação sobre a pandemia.

Palavras-chave: Autoridade médica. Ciência. Checagem. Desinformação. Divulgação científica.

\section{Information versus disinformation: the Covid-19 health crisis and the role of the medical authority in the dissemination of scientific knowledge}

\begin{abstract}
:
This article analyzes the phenomenon of disinformation in the medical authority discourse, in the context of the Covid-19 health crisis. The theoretical-methodological framework includes authors such as Epstein (2002), Mayor and Forti (1998), for questions related to the media, science and power; and theorists of discourse analysis, like Maingueneau (2004). The data collection was based on articles reviewed by the website of the Research Center for Communication and Journalism - NUJOC, from the Federal University of Piauí. The research corpus consists of ten articles in which a medical professional makes recommendations about the pandemic. The analysis consisted of the identification of the enunciators and their discursive positions regarding scientific knowledge. It was concluded that the doctors' individual knowledge is in conflict with the institutionalized knowledge of the health area, and that social networks play an important role in this conflict, providing the means for the dissemination of disinformation about the pandemic.
\end{abstract}

Keywords: Medical authority. Science. Checking. Disinformation. Scientific divulgation.

\footnotetext{
${ }^{1}$ Doutor em Comunicação, professor visitante da Universidade Federal do Piauí, bolsista PNPD/CAPES. E-mail: marcio.granez@hotmail.com

${ }^{2}$ Doutora em Comunicação, professora efetiva da Universidade Federal do Piaui.

E-mail:crisportela14@yahoo.com
} 


\title{
Información versus desinformación: la crisis de salud de Covid-19 y el papel de la autoridad médica en la difusión del conocimiento científico
}

\begin{abstract}
:
Este artículo analiza el fenómeno de la desinformación en el discurso de la autoridad médica, en el contexto de la crisis de salud del Covid-19. El marco teórico-metodológico incluye a autores como Epstein (2002), Mayor y Forti (1998), para cuestiones relacionadas con los medios, la ciencia y el poder; y teóricos del análisis del discurso, como Maingueneau (2004). La recolección de datos se detuvo en artículos verificados por el sitio web del Centro de Investigación en Comunicación y Periodismo - NUJOC, de la Universidad Federal de Piauí. El corpus de investigación consta de diez artículos en los que un profesional médico hace recomendaciones sobre la pandemia. El análisis consistió en la identificación de los enunciadores y sus posiciones discursivas sobre el conocimiento científico. Se concluyó que el conocimiento individual de los médicos está en conflicto con el conocimiento institucionalizado del área de salud, y que las redes sociales juegan un papel importante en este conflicto, proporcionando los medios para la difusión de desinformación sobre la pandemia.
\end{abstract}

Keywords: Autoridad médica. Ciencias. Comprobación. Desinformación. Divulgación científica.

\section{Introdução}

É inconcebível pensar a sociedade atual sem dimensionar o efetivo papel da ciência para a divulgação de conhecimentos sobre os mais diversos temas que permeiam o cotidiano do cidadão comum. Como acreditam Mayor e Forti (1998), a ciência é como uma caixa de Pandora, para a qual olhamos com um misto de medo, esperança e, às vezes, até terror, mas que se tornou um dos principais componentes de nosso dia a dia.

Nesse processo de divulgação de conhecimentos, a ciência busca aliados, como a mídia, que sejam capazes de ofertar para a sociedade informações científicas confiáveis e contribuam para desmistificar o preceito, muitas vezes bastante difundido, de que a ciência é inabalável, distante e dissociada da realidade do indivíduo comum.

Como um instrumento para a descoberta da "verdade" - o que "está por trás" -, a ciência não tem igual. Mesmo assim, deveríamos ser cautelosos em comemorar seus triunfos de modo demasiado acrítico, pois eles foram distribuídos desigualmente [...]. Em suas bem ordenadas explicações dos fenômenos naturais, a ciência deixa muita gente indiferente ou até alienada. O que a ciência nos diz pode ser verdadeiro, mas não é a única verdade que importa (MAYOR, 1998, p. 119-120).

Para que os indivíduos de maneira geral não fiquem indiferentes e/ou alienados frente ao que dizem os cientistas, enquanto porta-vozes da ciência, a informação apresenta-se como um importante e poderoso instrumento, que ajuda na formação de um pensamento crítico e questionador. Como advertem Mayor e Forti (1998), é preciso pensar mais na função social da 
ciência, reconhecendo que a ciência e o conhecimento científico são instrumentos poderosos e que a informação tornou-se pré-requisito essencial do desenvolvimento humano.

Dessa forma, o médico, como autoridade científica, possui enorme responsabilidade social frente às informações que divulga, contribuindo para esclarecer fatos e/ou situações que envolvem o conhecimento científico. No entanto, alguns cientistas, em função de interesses escusos, que, além de ideológicos, podem ser políticos, econômicos, etc., acabam contribuindo para obscurecer o teor científico das informações que apresentam à sociedade.

Diante do exposto, faz-se necessário investigar a construção discursiva dos profissionais da Medicina acerca do conhecimento sobre a Covid-19. Para tanto, o corpus da pesquisa é constituído por dez matérias publicadas, de maio a agosto de 2020, no site de checagem do Núcleo de Pesquisa em Jornalismo e Comunicação-NUJOC, da Universidade Federal do Piauí, o NUJOC Checagem. A coleta dos dados envolve apenas as matérias em que um profissional da área médica enuncia recomendações sobre a pandemia, tendo sido usada como ferramenta de busca as palavras-chave "médico" ou "médica". A análise levou em consideração a identificação dos enunciadores e suas posições discursivas frente ao conhecimento científico, tendo por base a fundamentação teórico-metodológica de autores como Epstein (2002), Mayor e Forti (1998), dentre outros que tratam de questões relacionadas à mídia, à ciência e ao poder. Esse referencial também inclui teóricos da análise do discurso, a exemplo de Maingueneau (2004).

\section{Mídia e poder: informação científica versus desinformação}

A informação, quando difundida com responsabilidade, seja através dos meios de comunicação tradicionais (impresso, rádio e televisão), seja através dos meios digitais (portais, sites e redes sociais digitais), surge como um instrumento imprescindível do qual o cidadão comum pode se valer para desenvolver o pensamento crítico e defender-se contra a “dominação" ideológica, muitas vezes imposta socialmente por governos, instituições, classes (FOUCAULT, 1972). No caso da informação científica, acercar-se dela faz com que o indivíduo desenvolva um antídoto contra a concepção, muitas vezes ampla e irresponsavelmente disseminada, de que o conhecimento científico é inquestionável.

Como destaca Mayor (1998), “o conhecimento em si mesmo é sempre positivo. O problema começa com a sua aplicação, que pode ser negativa ou até mesmo perversa" (MAYOR, 1998, p. 125). Isto revela que a informação científica pode, em alguns casos, 
chegar à população envolta por interesses, muitas vezes, marcadamente políticos e/ou econômicos, e estar a serviço de governos, laboratórios, indústrias farmacêuticas, dentre outros.

Além disso, "algumas dificuldades constituem obstáculos à popularização da ciência. Alguns cientistas, médicos e engenheiros condenam a mídia e lhe atribuem as atitudes e crenças ingênuas ou negativas que muitas pessoas têm sobre a ciência e a tecnologia" (EPSTEIN, 2002, p. 82). A mídia recebe a culpa por erros que, em muitos casos, são induzidos pelos próprios detentores do conhecimento científico.

Já foi o tempo em que a ciência podia ser compreendida como verdade absoluta ou definitiva, em que os cientistas, dotados de conhecimento especializado e/ou técnico, eram os senhores absolutos, com competência inquestionável para orientar governantes ou parlamentares nas escolhas sobre investimentos públicos em CT\&I e sobre o uso de tecnologias desenvolvidas (CALDAS, 2010, p. 34).

Dessa forma, na contramão da informação científica responsável e inequívoca, surgem discursos que remetem à desinformação (POSETTI; BONTCHEVA, 2020) e possuem algumas características peculiares, tais como: 1) aparentar ter caráter científico, mas ser compostos por fatos corriqueiros, pautados no senso comum; 2) contribuir para aumentar a complexidade da ciência frente ao público em geral, confundindo-o; 3) negar a própria ciência, dentre outras características.

No caso deste artigo, a análise realizada adiante recai sobre a construção discursiva dos profissionais da Medicina acerca do conhecimento sobre a Covid-19, partindo do princípio que os médicos possuem autoridade para validar os discursos que proferem a respeito de questões relacionadas à saúde. Como ressalta Maingueneau (2004):

O discurso só é discurso enquanto remete a um sujeito, um EU, que se coloca como fonte de referências pessoais, temporais, espaciais [...] e, ao mesmo tempo, indica que atitude está tomando em relação àquilo que diz e em relação a seu co-enunciador [...]. Ele indica, em particular, quem é o responsável pelo que está dizendo: um enunciado simples como "Está chovendo" é colocado como verdadeiro pelo enunciador, que se apresenta como responsável pelo enunciado, como o fiador de sua veracidade (MAINGUENEAU, 2004, p. 55).

Isto demonstra que a validação de um discurso só acontece de forma satisfatória quando a autoridade de quem diz, no caso o enunciador, não é questionada pelo destinatário do enunciado. No caso dos discursos analisados neste trabalho, o profissional da Medicina 
que o profere possui autoridade suficiente para se apresentar socialmente como portador de conhecimentos científicos e, por isso mesmo, pode emitir afirmações e/ou opiniões acerca dos mais variados temas científicos. Por isso, não seria diferente com as informações sobre a Covid-19.

Esse lugar de autoridade na área em que atua habilita o profissional da Medicina a organizar suas produções discursivas pautado em circunstâncias e/ou interesses que lhe sejam ideologicamente favoráveis. Foucault (2004) adverte que

em toda sociedade a produção do discurso é ao mesmo tempo controlada, selecionada, organizada e redistribuída por certo número de procedimentos que têm por função conjurar seus poderes e perigos, dominar seu acontecimento aleatório, esquivar sua pesada e temível materialidade (FOUCAULT, 2004, p. 8-9).

A chancela de autoridade em assuntos relacionados à ciência surge para o médico como uma questão que envolve poder. Nesse sentido, Roberto Machado (1981, p. 191-192) afirma que "poder é algo que se exerce, que funciona. E que funciona como uma maquinaria, como uma máquina social, que não está situada num lugar privilegiado ou exclusivo, mas que se dissemina por toda a estrutura social". Dessa forma, os atores sociais menos críticos e menos questionadores aceitariam os conhecimentos (im)postos socialmente por quem detém o poder. Tais atores já se satisfazem com a autoridade de quem fala, sem questionar interesses deliberadamente sutis por trás daquilo que é dito.

Caldas (2010), ao falar do poder dos cientistas sobre aquilo que é posto socialmente, nos instiga a alguns questionamentos:

O pesquisador detém o conhecimento, sem dúvida. Entretanto, é ele o dono da verdade? Afinal, o que é verdade? De que maneira a informação é construída até ser colocada em algum suporte midiático? Quais as condições de produção que interferem ou determinam a construção da notícia, reportagem, deste ou daquele modo; deste ou daquele tamanho? (CALDAS, 2010, p. 35).

Em muitos casos, esses questionamentos não são feitos pelo público em geral. Quando muito, são feitos pelos pares, por especialistas da área ou por pessoas mais dispostas a lançar um olhar crítico sobre algumas informações que, a priori, geram desconfianças, devido ao absurdo que carregam. Ou seja, a desinformação, que se apresenta sob a forma fake news ${ }^{3}$, é,

\footnotetext{
${ }^{3}$ Entendida aqui como informação falsa ou fora de contexto, produzida de forma intencional ou não, e que induz a erro sobre a realidade factual (UNESCO, 2019).
} 
em muitos casos, referendada por uma autoridade no assunto, que confere a essas notícias falsas um caráter fidedigno.

A mídia, em muitos casos, é responsabilizada por contribuir com esse processo de "desinformação social", pois não estabelece um padrão de checagem das informações que divulga, principalmente no âmbito do que dizem as fontes consultadas. Por vezes, os meios de comunicação oferecem voz a discursos de personalidades que já possuem o status de autoridade no assunto tratado e, por isso, tais discursos não são confrontados com outras vozes que poderiam questioná-los. Por isso, é importante adotar mecanismos de conferência das informações divulgadas, a exemplo do que faz o site NUJOC Checagem, contribuindo, assim, para dirimir dúvidas sobre temas de grande relevância social, como os científicos, analisados adiante neste artigo.

\section{Descrição do corpus da pesquisa}

O corpus da presente investigação está constituído por matérias do site de checagem do Núcleo de Pesquisa em Jornalismo e Comunicação-NUJOC, da Universidade Federal do Piauí. O NUJOC Checagem é um projeto de extensão dedicado a verificar conteúdo de desinformação, e tem uma seção voltada para a pandemia da Covid-19 desde março de 2020.

Usando como ferramenta de busca a palavra-chave "médico" ou "médica", foram localizadas dez matérias no período de maio a agosto de 2020 envolvendo orientações de um médico, no mais das vezes pelas mídias sociais digitais - Youtube, Facebook, Twitter e WhastApp. As mensagens analisadas recebem etiquetas - verdadeiro; falso; procede, mas se liga...; está sendo estudado; perdeu a linha; em busca de certezas - ao final do processo de verificação, para guiar o leitor sobre a veracidade do conteúdo da mensagem original. No entanto, no corpus desta pesquisa foram constatados apenas dois tipos de etiquetas: "falso" e "está sendo estudado".

O foco da presente investigação está na construção discursiva dos profissionais da Medicina acerca do conhecimento sobre a Covid-19, por isso, a coleta dos dados se deteve apenas nas matérias em que um profissional da área médica enuncia recomendações sobre a pandemia. Registre-se que o site acolhe mensagens sobre a Covid-19 de diversos outros tipos de enunciadores - políticos, enfermeiros, religiosos, leigos, artistas, entre outros. O Quadro 1 mostra um resumo das principais informações sobre as matérias analisadas.

As mensagens que foram objeto de checagem chegaram à equipe do NUJOC por meio das redes sociais, via contatos dos membros da equipe, ou por meio do aplicativo Eu Fiscalizo, da Fundação Oswaldo Cruz, com o qual o Núcleo tem parceria. Ao longo do 
período analisado, foram efetuadas mais de 100 checagens sobre a pandemia pela equipe do NUJOC, com cerca de metade delas oriundas de denúncias feitas pelo aplicativo Eu Fiscalizo.

O aplicativo recolhe denúncias de fake news feitas pela população e fornece um feedback ${ }^{4}$ para os denunciantes sobre a veracidade das informações após efetuado o trabalho de checagem por entidades parceiras.

Esse corpus de matérias foi submetido à análise, com base teórico-metodológica em autores previamente citados, como Epstein (2002), Mayor e Forti (1998), dentre outros que tratam de questões relacionadas à mídia, à ciência e ao poder. Essa base também inclui teóricos da Análise do Discurso, a exemplo de Maingueneau (2004). O procedimento de análise consistiu na identificação dos enunciadores (MACHADO, M. B., 2006) e suas posições discursivas frente ao conhecimento científico.

Quadro 1 - Resumo das matérias encontradas no site NUJOC Checagem

\begin{tabular}{|c|c|c|c|c|}
\hline DATA & $\begin{array}{l}\text { SÍNTESE DO } \\
\text { CONTEÚDO } \\
\text { VERIFICADO }\end{array}$ & $\begin{array}{l}\text { TÍTULO DA } \\
\text { MATÉRIA }\end{array}$ & ETIQUETA & $\begin{array}{c}\text { ENDEREÇO } \\
\text { ELETRÔNICO }\end{array}$ \\
\hline $04 / 05 / 20$ & $\begin{array}{l}\text { Suposta médica } \\
\text { sugere em vídeo no } \\
\text { WhastApp que } \\
\text { prender a } \\
\text { respiração serve } \\
\text { para diagnosticar } \\
\text { Covid-19 }\end{array}$ & $\begin{array}{l}\text { Prender a respiração } \\
\text { por } 10 \text { segundos não } \\
\text { serve como } \\
\text { diagnóstico contra a } \\
\text { Covid-19 }\end{array}$ & Falso & $\begin{array}{l}\text { http://nujocchecagem } \\
\text {.com.br/prender-a- } \\
\text { respiracao-por-10- } \\
\text { segundos-nao-serve- } \\
\text { como-diagnostico- } \\
\text { contra-a-covid-19/ }\end{array}$ \\
\hline $18 / 06 / 20$ & $\begin{array}{l}\text { Médico ortopedista } \\
\text { afirma em vídeo } \\
\text { que Remdesivir é } \\
\text { eficaz contra a } \\
\text { Covid }\end{array}$ & $\begin{array}{c}\text { Informação de } \\
\text { ortopedista sobre } \\
\text { escolha do } \\
\text { Remdesivir para } \\
\text { tratamento da Covid } \\
\text { - } 19 \text { é falsa }\end{array}$ & Falso & $\begin{array}{l}\text { http://nujocchecagem } \\
\text {.com.br/informacao- } \\
\text { de-ortopedista-sobre- } \\
\text { escolha-do- } \\
\text { remdezivir-para- } \\
\text { tratamento-da-covid- } \\
\text { 19-e-falsa/ }\end{array}$ \\
\hline $08 / 06 / 20$ & $\begin{array}{l}\text { Suposto médico } \\
\text { estabelece relação } \\
\text { entre o clima e o } \\
\text { novo coronavírus }\end{array}$ & $\begin{array}{l}\text { Clima quente não } \\
\text { favorece o Brasil na } \\
\text { luta contra o } \\
\text { coronavírus }\end{array}$ & $\begin{array}{l}\text { Está sendo } \\
\text { estudado }\end{array}$ & $\begin{array}{l}\text { http://nujocchecagem } \\
\text {.com.br/clima- } \\
\text { quente-nao-favorece- } \\
\text { o-brasil-na-luta- } \\
\text { contra-o-coronavirus/ }\end{array}$ \\
\hline $03 / 06 / 20$ & $\begin{array}{l}\text { Vídeo de médicos } \\
\text { traz informações } \\
\text { não comprovadas } \\
\text { sobre a Covid }\end{array}$ & $\begin{array}{c}\text { Médicos fazem } \\
\text { afirmações } \\
\text { controversas sobre a } \\
\text { Covid-19 }\end{array}$ & $\begin{array}{l}\text { Está sendo } \\
\text { estudado }\end{array}$ & $\begin{array}{l}\text { http://nujocchecagem } \\
\text {.com.br/medicos- } \\
\text { fazem-afirmacoes- } \\
\text { controversas-sobre-a- } \\
\text { covid-19/ }\end{array}$ \\
\hline $30 / 07 / 20$ & $\begin{array}{c}\text { Infectologista } \\
\text { afirma em vídeo } \\
\text { que Ivermectina é }\end{array}$ & $\begin{array}{l}\text { Covid-19: não há } \\
\text { evidência de que } \\
\text { Ivermectina elimine }\end{array}$ & Falso & $\begin{array}{l}\text { http://nujocchecagem } \\
\text {.com.br/covid-19- } \\
\text { nao-ha-evidencia-de- }\end{array}$ \\
\hline
\end{tabular}

\footnotetext{
${ }^{4}$ Entendido como retroalimentação do processo comunicativo (WOLF, 1984). Neste caso, é a resposta que o aplicativo fornece ao usuário sobre a veracidade da mensagem após efetuada a checagem.
} 


\begin{tabular}{|c|c|c|c|c|}
\hline & $\begin{array}{l}\text { eficaz contra a } \\
\text { Covid-19 }\end{array}$ & $\begin{array}{c}\text { 97\% dos vírus dentro } \\
\text { de células em } 48 \\
\text { horas }\end{array}$ & & $\begin{array}{l}\text { que-ivermectina- } \\
\text { elimine-97-dos- } \\
\text { virus-dentro-de- } \\
\text { celulas-em-48-horas/ }\end{array}$ \\
\hline $27 / 07 / 20$ & $\begin{array}{l}\text { Suposto médico diz } \\
\text { que máscaras criam } \\
\text { ambiente propício } \\
\text { para sobrevivência } \\
\text { do coronavírus }\end{array}$ & $\begin{array}{l}\text { Médico traz } \\
\text { informações falsas ao } \\
\text { rejeitar o uso de } \\
\text { máscaras como } \\
\text { prevenção para a } \\
\text { Covid - } 19\end{array}$ & Falso & $\begin{array}{l}\text { http://nujocchecagem } \\
\text {.com.br/medico-traz- } \\
\text { informacoes-falsas- } \\
\text { ao-rejeitar-o-uso-de- } \\
\text { mascaras-como- } \\
\text { prevencao-para-a- } \\
\text { covid-19/ }\end{array}$ \\
\hline $17 / 08 / 20$ & $\begin{array}{l}\text { Em vídeo, pediatra } \\
\text { defende } \\
\text { automedicação } \\
\text { contra a Covid-19 }\end{array}$ & $\begin{array}{l}\text { Médico pediatra } \\
\text { defende } \\
\text { automedicação com } \\
\text { hidroxicloroquina, } \\
\text { ivermectina e } \\
\text { azitromocina }\end{array}$ & Falso & $\begin{array}{l}\text { http://nujocchecagem } \\
\text {.com.br/medico- } \\
\text { pediatra-defende- } \\
\text { automedicacao-com- } \\
\text { hidroxicloroquina- } \\
\text { ivermectina-e- } \\
\text { azitromocina/ } \\
\end{array}$ \\
\hline $18 / 08 / 20$ & $\begin{array}{l}\text { Médico afirma que } \\
\text { pandemia é farsa } \\
\text { criada com } \\
\text { finalidades políticas }\end{array}$ & $\begin{array}{l}\text { Médico utiliza dados } \\
\text { falsos ao tentar } \\
\text { deslegitimar a } \\
\text { pandemia de } \\
\text { COVID-19 }\end{array}$ & Falso & $\begin{array}{l}\text { http://nujocchecagem } \\
\text {.com.br/medico- } \\
\text { utiliza-dados-falsos- } \\
\text { ao-tentar- } \\
\text { deslegitimar-a- } \\
\text { pandemia-de-covid- } \\
\text { 19/ }\end{array}$ \\
\hline $21 / 08 / 20$ & $\begin{array}{l}\text { Médica associa a } \\
\text { pandemia à falta de } \\
\text { exposição ao sol }\end{array}$ & $\begin{array}{l}\text { Médica afirma que } \\
\text { falta de sol é causa } \\
\text { principal da } \\
\text { pandemia }\end{array}$ & $\begin{array}{l}\text { Está sendo } \\
\text { estudado }\end{array}$ & $\begin{array}{l}\text { http://nujocchecagem } \\
\text {.com.br/medica- } \\
\text { afirma-que-falta-de- } \\
\text { sol-e-causa- } \\
\text { principal-da- } \\
\text { pandemia/ }\end{array}$ \\
\hline $05 / 08 / 20$ & $\begin{array}{l}\text { Médico e político } \\
\text { defendem } \\
\text { tratamento } \\
\text { profilático à base } \\
\text { de Ivermectina } \\
\text { contra a Covid-19 }\end{array}$ & $\begin{array}{l}\text { Ivermectina pode } \\
\text { impedir a replicação } \\
\text { do vírus em seres } \\
\text { humanos? }\end{array}$ & $\begin{array}{l}\text { Está sendo } \\
\text { estudado }\end{array}$ & $\begin{array}{l}\text { http://nujocchecagem } \\
\text {.com.br/ivermectina- } \\
\text { pode-impedir-a- } \\
\text { replicacao-do-virus- } \\
\text { em-seres-humanos/ }\end{array}$ \\
\hline
\end{tabular}

Fonte: Quadro elaborado pelos autores (2021).

As mensagens que foram objeto de checagem chegaram à equipe do NUJOC por meio das redes sociais, via contatos dos membros da equipe, ou por meio do aplicativo Eu Fiscalizo, da Fundação Oswaldo Cruz, com o qual o Núcleo tem parceria. Ao longo do período analisado, foram efetuadas mais de 100 checagens sobre a pandemia pela equipe do NUJOC, com cerca de metade delas oriundas de denúncias feitas pelo aplicativo Eu Fiscalizo. 
O aplicativo recolhe denúncias de fake news feitas pela população e fornece um feedback ${ }^{5}$ para os denunciantes sobre a veracidade das informações após efetuado o trabalho de checagem por entidades parceiras.

Esse corpus de matérias foi submetido à análise, com base teórico-metodológica em autores previamente citados, como Epstein (2002), Mayor e Forti (1998), dentre outros que tratam de questões relacionadas à mídia, à ciência e ao poder. Essa base também inclui teóricos da Análise do Discurso, a exemplo de Maingueneau (2004). O procedimento de análise consistiu na identificação dos enunciadores (MACHADO, M. B., 2006) e suas posições discursivas frente ao conhecimento científico.

\section{A autoridade médica e a construção discursiva da (des)informação científica}

As mensagens reunidas no corpus desta investigação apontam para o conflito entre a autoridade de médicos e a das instituições de saúde, opondo a experiência clínica individual às orientações que guiam as entidades representativas do campo da Medicina. Nas mensagens, são recorrentes algumas características, que se pretende explicitar a partir de agora, reunidas em três grupos de enunciações discursivas. Os resultados a seguir se baseiam nas mensagens examinadas pela agência.

\section{Testemunho como prova}

Observa-se que a experiência clínica tem sido o parâmetro usado para embasar as recomendações dos médicos nas matérias analisadas. Os anos de trabalho surgem como a prova da veracidade das informações. A autoridade repousa aqui nos anos de experiência clínica, que são explicitamente mencionados como fator de credibilidade para as recomendações enunciadas pelos médicos. Essa experiência clínica só tem por testemunho o próprio médico e sua palavra, sendo desprezados os argumentos e fatos em contrário, eventualmente citados pelos profissionais, como manipulação decorrente de interesses escusos.

Em primeiro plano, coloca-se o relato de casos de sucesso envolvendo curas e tratamentos profiláticos, aplicados a pacientes ou aos familiares do médico e ao próprio médico que enuncia a mensagem. A prova estaria assim ancorada na experiência imediata resultante do trabalho clínico. O médico anuncia, por exemplo, que, "em 30 anos de clínica",

\footnotetext{
${ }^{5}$ Entendido como retroalimentação do processo comunicativo (WOLF, 1984). Neste caso, é a resposta que o aplicativo fornece ao usuário sobre a veracidade da mensagem após efetuada a checagem.
} 
já curou "vários" ou "centenas" de pacientes com tal medicação. Não se faz menção, via de regra, a estudos científicos que comprovem essa experiência de forma sistemática.

Assim, em várias das mensagens envolvendo medicamentos, como a cloroquina e a ivermectina, o médico apela aos números de sua experiência clínica, sem mencionar as orientações oficiais, ou mencionando-as para desqualificá-las. O testemunho é usado como prova principal, e não a experiência acumulada pela coletividade da categoria médica, nem as orientações que decorrem dessa coletividade.

A par da experiência clínica como parâmetro, há também um discurso que remete às soluções simples, ao alcance de todos, e também baseado na experiência do profissional - só que, nesse caso, a experiência de vida, que é trazida como modelo a ser seguido. Alimentação saudável, luz solar, remédios comuns encontrados nas farmácias: a lista de soluções para a Covid-19 é longa e recorrente. Aqui se observa a enunciação de um discurso que remete a soluções tradicionais e caseiras, que estariam sendo desprezadas pelos interesses dos grandes grupos econômicos e pelo sistema que governa o mundo com fins voltados ao lucro.

O formato dado a esses relatos também contribui para reforçar-lhes o apelo. Trata-se basicamente de depoimentos, sem margem para a controvérsia, e com referência a fontes que apenas confirmam a veracidade da mensagem. É como se o médico estivesse conversando com o paciente em seu consultório, olho no olho.

Embora com grau variado de domínio das técnicas de comunicação e retórica, percebe-se um ambiente de proximidade e de empatia que, somadas à autoridade tradicionalmente associada à figura do médico, tendem a potencializar a efetividade da mensagem.

\section{Rebeldia como qualidade}

A insurgência contra as orientações oficiais da área da saúde é utilizada como um argumento a mais para reforçar a postura independente dos profissionais que se rebelam contra o sistema. Em algumas das ocorrências, esse discurso está marcado pela agressividade e pelo viés político-ideológico. Nesses casos, o profissional faz a denúncia da opressão e das contradições de órgãos oficiais, como a Organização Mundial da Saúde (OMS) e a Organização Pan-Americana da Saúde (OPAS), mostrando, por exemplo, a mudança de postura dessas entidades ao longo da pandemia, como no caso da cloroquina, cuja indicação foi revista mais de uma vez pela OMS. 
Não é incomum que tais enunciações estejam marcadas pela virulência no nível da linguagem, observando-se invectivas e eventualmente calão endereçados aos representantes da posição oficial dos órgãos representativos da categoria médica e dos governos.

Ao denunciarem a opressão sofrida, os profissionais se colocam como cientistas que lutam contra o sistema hierárquico e burocrático - quiçá também corrupto -, que está distante da realidade da população. A crítica com viés político se soma a esse discurso, pois os profissionais também denunciam supostos interesses de cunho ideológico que estariam por detrás de certas posturas das entidades oficiais.

O suporte das mídias digitais deu ao discurso desses profissionais uma amplitude inaudita, contribuindo para reforçar a aura de rebeldia e independência, pois eles também se colocam contra a grande mídia, que não lhes daria espaço para compartilharem a boa-nova que trazem de sua experiência particular.

Em alguns casos, o profissional explicita o caráter independente de suas mensagens, vinculando-o à independência permitida pelo suporte: um canal no Youtube, uma página no Facebook, uma conta no Instagram etc. Nesses canais, por supostamente serem mais independentes, também não haveria distorção da verdade, que eles se propõem a revelar. Assim, os intermediários tradicionais teriam sido eliminados, permitindo ao profissional da área médica o contato direto com a audiência, sem rodeios e sem as burocracias do sistema.

O jornalismo, via de regra, é colocado ao lado do sistema, como fator de distorção e de ocultamento da verdade. A grande mídia teria interesse em calar as vozes dissonantes, e, por isso, não seria confiável, já que está submetida a interesses comerciais e sempre pronta a distorcer as informações. A intermediação e o debate, o questionamento e a controvérsia são eliminados nessas enunciações dos profissionais médicos, assim como a análise pelos pares da comunidade médica e científica.

Em algumas dessas mensagens, os canais de comunicação direta trazidos pela revolução online são celebrados em termos explícitos, incentivando-se a produção e disseminação de conteúdo verdadeiro por meio deles. Parece haver um sentido de rebeldia e de combate às trevas nessas enunciações, que remete talvez ao desvelar de uma verdade que está aí diante dos olhos de todos, mas que ninguém antes teve a coragem de enunciar.

\section{Cura trazida do "Primeiro Mundo"}

Em várias das mensagens, o profissional salienta a procedência da informação, 
vinculando-a a países tomados como parâmetro de desenvolvimento - como Estados Unidos, Israel e alguns países europeus. Em algum momento da fala dos médicos, o dado da nacionalidade dos pesquisadores ou do instituto de pesquisa é mencionado, a fim de chancelar a validade da informação.

Um exemplo recorrente é a pesquisa desenvolvida por cientistas italianos sobre os benefícios da exposição ao sol e a correlação encontrada entre os níveis de vitamina $\mathrm{D}$ e o número de óbitos pela Covid-19. O estudo, que foi conduzido na universidade de Turim, na Itália, pelos professores de Geriatria Giancarlo Isaia e de Histologia Enzo Medico, foi mencionado em mais de uma mensagem submetida à checagem do NUJOC, tanto por leigos como por profissionais da Medicina.

Embora o estudo não tenha sido comprovado nem a correlação confirmada por métodos mais aprofundados, ele acabou servindo como base para as recomendações de médicos que, já de início, enfatizam a nacionalidade dos autores da pesquisa como fator que legitimaria as conclusões obtidas. Com isso, reforça-se a autoridade da informação, sem submetê-la ao crivo de outros estudos já disponíveis sobre o assunto. As checagens efetuadas pelo NUJOC levantaram, mediante pesquisa no buscador Google, diversas refutações do estudo dos cientistas italianos, mostrando o caráter ainda inicial da pesquisa e a relativização dos resultados pelos próprios autores.

Nesse sentido, o que guia a construção discursiva dos médicos parece ser o seguinte raciocínio: para a população que acessa as redes sociais digitais, vincular uma informação a um centro de pesquisa estrangeiro é motivo de credibilidade. Não se entra na discussão técnica sobre o estágio da pesquisa referida nem sobre as credenciais dos estudiosos citados, embora esses dados possam ser facilmente acessados pelas ferramentas de comunicação disponíveis. A autoridade que vem de longe, de um país mais avançado, seria o bastante para o convencimento.

A título de complementação, observa-se que a atribuição da autoridade a estrangeiros por pessoas leigas é também recorrente. Na fala de outros atores do processo comunicativo, como um pastor evangélico, a informação sobre a cura da Covid-19 por bicarbonato de sódio e limão, por exemplo, foi atribuída a um parente que teria viajado a Israel. E Israel, ainda segundo o pastor, não teria problemas com a pandemia, justamente por obra da receita de bicarbonato com limão (BICARBONATO..., 2020).

A construção discursiva apresenta aqui um viés de revelação que envolve o saber 
especializado - o domínio de uma língua estrangeira, o acesso a informação restrita a pesquisadores - e a sua tradução e circulação para o público mais amplo, por meio da simplificação e da abordagem informal. Revelar de início que a informação veio "da Itália" ou de "um estudo de Oxford" teria o condão de provar a veracidade da informação, por mais improvável ou discutível que ela seja.

\section{Síntese: o conhecimento científico em xeque}

Um olhar sobre o corpus permite observar diversas construções discursivas que explicitam formas de combate à ciência e aos métodos jornalísticos de construção de evidência factual. Em todas elas, perpassa o conflito entre o saber construído pela comunidade científica e a experiência individual dos profissionais que enunciam suas descobertas e orientações à população.

A credibilidade tradicionalmente associada à palavra do médico ganha uma dimensão midiática inaudita, levando milhares e milhões de enunciatários a questionar verdades já bem estabelecidas pelo senso comum e pela ciência - a efetividade das vacinas, o perigo da automedicação, a ineficácia de grande parte dos remédios caseiros.

Nas matérias analisadas, identificamos três formações discursivas que ilustram esse conflito, enunciadas pelos médicos cujas mensagens foram objeto de checagem da equipe do NUJOC. A primeira delas diz respeito à contraposição entre a experiência clínica individual e a posição institucional da categoria médica. A forma de enunciação das mensagens, privilegiando o contato intimista, remete a uma conversa franca com seu médico(a). A experiência e o testemunho individual são contrapostos ao saber acumulado pela categoria médica.

A segunda formação identificada diz respeito à postura de rebeldia frente ao establishment da saúde e político. O profissional explicita aqui uma postura de combate contra o sistema e os interesses sub-reptícios das instituições tradicionais. Nesses casos, o suporte midiático das redes sociais representaria um aliado e uma alternativa para que essas vozes dissidentes possam chegar à população.

Finalmente, na terceira formação discursiva que identificamos no corpus, os enunciadores fazem referência à origem estrangeira da informação que se propõem divulgar. Essa origem, supostamente vinculada a um país mais desenvolvido ou de primeiro mundo, chancelaria a veracidade da informação. O médico traz a boa-nova como quem compartilha 
uma verdade óbvia que estava sempre aí. Aqui o profissional se coloca como um tradutor ou divulgador do conhecimento até então escondido por grupos de interesse, facilitando o acesso ao conhecimento legítimo e superior.

\section{Considerações finais}

A eclosão da pandemia da Covid-19 trouxe à tona o conflito entre a autoridade científica e a experiência individual da classe médica, explicitando a necessidade de compreender os limites e as lições desse conflito. O presente artigo fez uma reflexão acerca da questão da autoridade da ciência, no contexto das transformações por que passa a mídia e a comunicação (CALDAS, 2010).

O corpus de análise, constituído por checagens sobre informações referentes à pandemia da Covid-19, explicitou as formas discursivas da desinformação sobre a doença. Baseado em matérias que partem de orientações de profissionais da área médica, o conjunto de checagens analisadas demonstra um conflito explícito entre instituições e práticas individuais. A autoridade do médico é tomada como parâmetro para a orientação via redes sociais digitais e outras formas de divulgação largamente empregadas desde o início da revolução digital.

Em conflito com as orientações oficiais da área médica, como as emanadas pela OMS, o Conselho Federal de Medicina, e as sociedades científicas especializadas, a postura dos referidos médicos sobrepõe sua prática e experiência clínica ao discurso oficial da categoria. A desinformação se alimenta dessa dinâmica. Gera-se uma série de dúvidas sobre procedimentos de cuidado, que vão da prevenção ao tratamento da doença, com maior prejuízo sobretudo aos que não dispõem de acesso à informações especializadas.

Em boa parte do discurso dos profissionais que vão de encontro às orientações da categoria, tem-se a prova ancorada no relato da experiência e nos anos de prática clínica. Usase tal experiência como argumento e ponto de partida. Para além disso, há também um viés político e ideológico em parte dessas mensagens. Trata-se de um discurso que denuncia a coerção e a pressão das instituições oficiais, que são elas, sim, tachadas de ideológicas e enviesadas politicamente.

Várias das matérias reunidas no corpus apresentam a denúncia da opressão do discurso oficial, que seria imposto à categoria médica sem fundamento razoável. O uso das mídias sociais digitais por esses profissionais - Facebook, Youtube, WhatsApp, entre outros - tende a 
potencializar as recomendações e elevá-las à categoria de remédio ou cura, chanceladas pela autoridade de um médico. Some-se a isso a aura de um médico perseguido por trazer verdades que as corporações querem esconder da população - a cloroquina como cura, a ivermectina como tratamento profilático, o uso de máscaras como tentativa de silenciar a população - e tem-se uma formação discursiva que remete talvez à vida dos mártires e santos.

Outra recorrência observada no discurso dos profissionais que se insurgem contra a posição oficial da categoria diz respeito à origem estrangeira de informação privilegiada. Nesses casos, o médico seria como o porta-voz da boa-nova, um divulgador de informação privilegiada que, por alguma razão, a mídia está tentando esconder da população.

Neste conflito entre as posições oficiais da categoria médica e a postura dos profissionais médicos que individualmente se insurgem contra as orientações oficiais, o discurso acaba por se constituir no principal campo de batalha (FOUCAULT, 2004; MACHADO, M. B., 2006; CALDAS, 2010). As estratégias discursivas utilizadas para conquistar a credibilidade se mostram articuladas com as tecnologias da comunicação, com largo uso das mídias sociais e abordagem intimista, simulando o contato face a face.

Observa-se a autorreferencialidade das redes sociais digitais, via de regra exaltadas como veículos mais confiáveis do que a imprensa e a mídia tradicional. Também se observa o uso confessional das mídias sociais digitais, com o médico dirigindo-se à audiência de forma intimista, numa linguagem desprovida de formalidades. Ao mesmo tempo, o saber especializado do profissional é chancelado pela adoção de procedimentos e rituais também especializados. É o caso do conhecimento de línguas estrangeiras, e do acesso a publicações científicas de outros países, que tornam a figura do médico um intermediário necessário entre o saber e o não-saber.

Todas essas práticas enunciativas revelam um conflito explícito entre médicos e classe médica, entre conhecimento empírico e conhecimento sistematizado e verificado pelos pares, entre crenças individuais e método científico (MACHADO, R., 1981; MAYOR, 1998; CALDAS, 2010). Ao enunciarem suas descobertas e recomendações via redes sociais digitais, os profissionais da área médica expõem as fissuras no edifício da ciência e provocam o trabalho de checagem de informações por parte do jornalismo.

Ciência e jornalismo têm no método de aproximação da verdade factual o seu trunfo na busca pelo conhecimento da realidade. Ambos estão sendo chamados a unir esforços para reconstruir o edifício da racionalidade. Neste artigo, buscamos contribuir com esse esforço. 
Referências

BICARBONATO não salvou Israel da pandemia. NUJOC Checagem, Teresina, 10 jun., 2020. Disponível em: http://nujocchecagem.com.br/bicarbonato-nao-salvou-israel-dapandemia/. Acesso em: 10 set. 2020.

CALDAS, Graça. Divulgação científica e relações de poder. Informação \& Informação, Londrina, v. 15, n. esp., p. 31-42, 2010. Disponível em: http://www.uel.br/revistas/uel/index.php/informacao/article/view/5583. Acesso em: 19 set. 2020.

EPSTEIN, Isaac. Divulgação científica: 96 verbetes. Campinas: Pontes, 2002.

FOUCAULT, Michel. A ordem do discurso. São Paulo: Loyola, 2004.

FOUCAULT, Michel. Arqueologia do saber. Petrópolis, RJ: Vozes, 1972.

MACHADO, Roberto. Ciência e saber: a trajetória da arqueologia de Foucault. Rio de Janeiro: Graal, 1981.

MACHADO, Marcia Benetti. Jornalismo e perspectivas de enunciação: uma abordagem metodológica. Intexto, Porto Alegre, v. 1, n. 14, p. 1-11, jan./jun. 2006. Disponível em: https://seer.ufrgs.br/intexto/article/view/4251. Acesso em: 10 jun. 2019.

MAINGUENEAU, Dominique. Análise de textos de comunicação. 3. ed. São Paulo: Cortez, 2004.

MAYOR, Frederico. Ciência e poder hoje e amanhã. In: MAYOR, Frederico; FORTI, Auguto (org.). Ciência e poder. Campinas, SP: Papirus; Brasília: UNESCO, 1998. p. 119-144.

MAYOR, Frederico; FORTI, Augusto (org.). Ciência e poder. Campinas, SP: Papirus; Brasília: UNESCO, 1998.

POSETTI, Julia; BONTCHEVA, Kalina. Desinfodemic: deciphering COVID-19 desinformation. Paris: Unesco, 2020. Disponível em: https://en.unesco.org/sites/default/files/disinfodemic_deciphering_covid19_disinformation.pd f. Acesso em: 20 jun. 2020.

UNESCO. Jornalismo, fake news \& desinformação: manual para educação e treinamento em jornalismo. Paris: Unesco, 2019.

WOLF, Mauro. Teorias da comunicação. Lisboa: Presença, 1984.

Submetido em 25.09.2020

Aprovado em 09.01.2020 